\title{
Impact of Aging on the Quality of Life of Workers with Intellectual Disabilities
}

\author{
José Luis CUESTA GOMEZ, Raquel DE LA FUENTE-ANUNCIBAY, \\ María Teresa ORTEGA CAMARERO and Jerónimo GONZÁLEZ BERNAL
}

\author{
Universidad de Burgos
}

(Received on November 13, 2019, Accepted on May 7, 2020)

\begin{abstract}
The increased life-expectancy of people with intellectual disability is generating new needs for attention and care that can assist healthy aging. This question is accentuated among workers from Special Employment Centers, for whom aging has a twofold impact, in so far as it interferes with their professional development and their means of earning a living. A study is conducted with a sample of 49 workers from a Special Employment Center, with the objective of analyzing the quality of life of people with intellectual disability. The information was gathered with the INICO-FEAPS Integral Evaluation Scale of the Quality of Life of People with Intellectual Disability. The Mann-Whitney U test; Spearman test and Anova are used for data analysis. The results highlighted the importance of age on quality-of-life deterioration, evident from lower scores for emotional wellbeing, social inclusion and social relations, among others, as well as the differences according to gender and training of the group. The need is noted to establish challenges and proposals that will minimize the negative impacts of aging on the journey towards a non-active stage. One limitation of the study is the need for larger sample sizes.
\end{abstract}

Keywords: Aging; Quality of Life; Intellectual Disability; Employment.

\section{Impacto del envejecimiento en la calidad de vida de los trabajadores con discapacidad intelectual}

RESUMEN: El incremento en la esperanza de vida de las personas con discapacidad intelectual está generando nuevas necesidades de atención y cuidados que garanticen un envejecimiento saludable. Esta cuestión se acentúa en los trabajadores de los Centros Especiales de Empleo, para quienes el envejecimiento impacta doblemente al interferir en su desempeño profesional y su medio de vida. Con el objetivo de analizar la calidad de vida de personas con discapacidad intelectual, se realiza un estudio con una muestra de 49 trabajadores de un centro especial de empleo. La recogida de información se realiza mediante la Escala INICO-FEAPS de Evaluación Integral de la Calidad de Vida de Personas con Discapacidad Intelectual o del Desarrollo. Se realizan las pruebas U de Mann-Whitney; correlación de Spearman y Anova para el análisis de datos. Los resultados señalan la importancia de la edad en el deterioro de la calidad de vida que se manifiesta en peores puntuaciones en el bienestar emocional, inclusión social y relaciones interpersonales, entre otras, así como diferencias según el sexo y formación del colectivo. Se constata la necesidad de establecer 
retos y propuestas que minimicen los impactos negativos del envejecimiento en el tránsito hacia una etapa no activa. Es necesario ampliar el estudio con muestras más grandes.

Palabras clave: envejecimiento; calidad de vida; discapacidad intelectual; empleo.

Correspondencia: Raquel de la Fuente Anuncibay. raquelfa@ubu.es

\section{Introduction}

Over recent years, aging processes have attracted greater interest, in a Society that appears to have lost the values formerly associated with the fact of becoming old. 2012 was declared the Year of Active Ageing and Intergenerational Solidarity by the European Union, calling attention to the many difficulties that older people face, as well as the numerous activities in which they are or could be involved, if facilitated appropriate channels.

People with Intellectual and Developmental Disabilities (IDD) have considerably increased their life expectancy, due to improved health treatment; an increasing number of care services of better quality, as well as the far-reaching changes that have taken place over recent years with regard to the provision of support services (Aguado \& Alcedo, 2004; Otamendi \& Navas, 2018). The aging of people with IDD has become a new social debate and an emergent issue that has been attracting the interest of all social organizations with direct involvement in the matter (Rodríguez 2010; Navas; Uhlmann \& Berasategui, 2014; Rafanell, 2017; Berjano \& García, 2010).

The CERMI ${ }^{1}$ working group on active aging has pointed to the challenges that people will have to face for successful aging; such as their own aging process and coping with the indifference of society (Cayo \& Andreu, 2012). In the case of people with disability, a third obstacle is added: their own disability, which leaves them facing unequal opportunities with regard to other groups of people.

Aging is not exclusive to people with intellectual disability, but it manifests itself with distinctive features. Different sectors of society have, for some decades now, been seeking greater knowledge of this key stage of life: old age (Vidriales, Hernández \& Plaza, 2016). Over recent years, investigations and studies on aging among people with IDD have been expanding, producing ever-greater numbers of publications and technical documents that attempt to identify their needs and priority lines of action (Navas et al., 2014).

However, some authors such as Aguado and Alcedo (2004; 2010); Berjano and García, (2010); Berzosa, (2013); Elorriaga; Restrepo; Bayarri and Fillat, (2012); Novell; Nadal; Smilges; Pascual and Pujol, (2008); Verdugo; Rodríguez-Aguilera and Sánchez-Gómez, (2009), pointed to the lack of scientific attention given to mature ages and old age in relation to intellectual disability, because investigations had mainly centered on earlier stages (Rodríguez, 2010).

The analysis of the needs of people with IDD who are aging have been covered in various studies which can contribute an integral overview of the problem: relying on the opinions of both the people who are aging and their professional carers, as Del Barrio and Santurde (2015) pointed out; looking at professionals and families, as discussed in Novell et al., 2008, and Berjano and García, 2010; and, the managers of care services, as proposed in Elorriaga et al. (2012).

1 Comité Español de Representantes de Personas con Discapacidad [Spanish Committee of Representatives of People with Disability]

(C) Psy, Soc, \& Educ, 2020, Vol. 12(2) 
The analysis of the impact of aging on workers with intellectual disability has yet to be undertaken, on the basis of the consequences that aging has on the quality of life of each person. This concept has been developing, since the first analysis of wellbeing up until the current dimension of personal assessment, through the use of indicators for the evaluation of the results (Verdugo, Schalock, Arias, Gómez \& Jordán, 2013).

In this field, Schalock and Verdugo (2002) proposed a new approach of the analysis of the quality of life of people with IDD, in which they established eight central dimensions (emotional wellbeing; interpersonal relations; material wellbeing; personal development; physical wellbeing; self-determination; social inclusion and rights) with a series of indicators as the basis of what quality of life should be. This quality of life model is one of the references for the organization of services, the identification of its problems, and the evaluation of its functional operation (Novell et al., 2008).

Most studies on the quality of life of the aging processes of people with IDD emphasize certain aspects as the most relevant quality-of-life indicators: health and health care; existing resources; the role of the family; and the quality of care and social support. In that respect, some authors (Aguado et al. 2010) have pointed to some of the variables with greater impact on the effects of aging than age itself, such as those relating to health, specific dysfunctions, and the availability of support, and needs that are treated.

On the basis of that context, we will analyze how aging and premature deterioration among workers with disability over 45 years of age has impacted on their quality of life. The collective is especially complex, because the process of deterioration will impact on the worker from a triple perspective that is multiplied: aging, intellectual disability, and changes in their working life.

\section{Method}

\section{Participants}

The study involves 49 people with intellectual disability all of whom are workers at a Centro Especial de Empleo (CEE) de Iniciativa Social [Social Initiative Special Employment Center]. Non-probabilistic sampling was performed. The sample was representative of the population with intellectual disability at work in the CEEs of the Regional Government of Castile and Leon (Junta de Castilla y León, 2018), in terms of the variables gender, age, and disability.

The workers were between 25 and 63 years old. The age band of 45 years old and over was of special interest for the purposes of this investigation: 29 people aged under 45 participated and 19 were older than 45 years old. The distribution by gender was 19 women and 30 men. The majority of them $(n=41)$ are people with intellectual disability, and there were 8 cases of double diagnosis with mental illness. With respect to their employment activity, 22 people were workers from the industrial sector; 17 were operators of services; 6 people worked in gardening, and 3 in recycling.

As regards the domestic situation: 13 lived in the family home, and 36 in supervised homes of whom 10 lived in residential spaces and 26 people lived in homes with different levels of supervision. The majority $(\mathrm{n}=42)$ lived in urban areas. 


\section{Instruments}

The Escala INICO-FEAPS. Evaluación Integral de la Calidad de Vida de personas con Discapacidad Intelectual o del Desarrollo [The INICO-FEAPS Scale. Integral Assessment of the Quality of Life of People with IDD] (Verdugo, Gómez, Arias, Santamaría, Clavero \& Tamarit, 2013) was used to collect the information. The scale has been validated for its administration to people with IDD aged 18 or older, no longer in education, employed in some type of professional, manual, or occupational activity. It is at present the reference scale for analyzing the quality of life of adults with intellectual disability in employment. The scale has a Cronbach alpha coeffiicent of ,893 for self report, and ,937 for other people's report..

The instrument has two subscales: a "self-administered report" and a "report completed by other people" (professionals and families). In our study, the second scale was administered, which contains 72 items expressed in the third person and with four-point Likert-type responses.

\section{Measures}

The eight Quality-of-Life dimensions were used as the dependent variables. A descriptive analysis of the data related to gender, age, the type of disability, the place of residence, and employment activity was completed. The Mann-Whitney U-test for independent samples and ANOVA were used for means testing, the means were compared between the Quality-of-Life index and the scores for the 8 dimensions as a function of different variables; age, gender, education, and place of residence.

\section{Results}

The data with respect to the variable age indicated that significant differences existed for the individuals under 45 years of age, $\mathrm{p}=.02$.

Table 1. Analysis of the quality-of-life index among people older and younger than 45 years of age. Mann-Whitney U test.

\begin{tabular}{lllcc}
\cline { 3 - 4 } & & N & Average range & Sum of ranges \\
\hline \multirow{3}{*}{ Quality of life index } & Younger than 45 & 27 & 27.89 & 753.00 \\
& Older than 45 & 20 & 18.75 & 375.00 \\
& Total & 47 & & \\
\hline
\end{tabular}

$\mathrm{P}=.023$

The correlation tests indicated that the individuals under 45 years of age had a higher percentage score for quality of life (57.4\%) than those over 45 (42.6\%). Having tested the means obtained with the different age ranges, we can see that the individuals under 45 years of age obtained higher means, and that the quality of life worsened as the age increased, except in the case of those situated in the interval 39-44 ( $\overline{\mathrm{X}}=11.75)$.

Psy, Soc, \& Educ, 2020, Vol. 12(2) 
Table 2. Means test of the scores for the quality of life index by age ranges

\begin{tabular}{lcc}
\cline { 2 - 3 } & $\mathrm{N}$ & Average \\
\hline $25-31$ & 8 & 16.38 \\
$32-38$ & 11 & 18.18 \\
$39-44$ & 8 & 11.75 \\
$>45$ & 20 & 12.11 \\
Total & 47 & 14.47 \\
\hline
\end{tabular}

$.159<\mathrm{p}<1$; except $39-44$ vs $32-38=.014 ;>45$ vs $32-38=.024$

With regard to the results of each indicator that defines the Quality of Life, better scores within the range of average scores were obtained for individuals under 45 years of age in all the dimensions, except in the dimension of rights for which the average range (24.34) was slightly under the average range for people over 45 years of age (24.73).

There were significant differences in three of the eight dimensions under analysis: thus, the people over 45 years of age had better emotional wellbeing $(p=.034)$; the social inclusion of those under 45 years was greater $(\mathrm{p}=.006)$ and they had better interpersonal relations $(\mathrm{p}=.002)$, in other words, they presented higher assessments for their family, social, and sexually affective relations.

Table 3. Test of scores for the quality-of-life dimensions. Mann-Whitney U test

\begin{tabular}{|c|c|c|c|c|}
\hline & & & & \\
\hline & Age & $\mathbf{N}$ & Average range & $\mathbf{p}$ \\
\hline \multirow[t]{2}{*}{ Self-determination } & Younger than 45 & 28 & 25.77 & .450 \\
\hline & Older than 45 & 20 & 22.73 & \\
\hline \multirow[t]{2}{*}{ Rights } & Younger than 45 & 28 & 24.34 & .924 \\
\hline & Older than 45 & 20 & 24.73 & \\
\hline \multirow[t]{2}{*}{ Emotional wellbeing } & Younger than 45 & 28 & 28.09 & .034 \\
\hline & Older than 45 & 20 & 19.48 & \\
\hline \multirow[t]{2}{*}{ Social inclusion } & Younger than 45 & 28 & 29.20 & .006 \\
\hline & Older than 45 & 20 & 19.73 & \\
\hline \multirow[t]{2}{*}{ Personal development } & Younger than 45 & 28 & 24.57 & .966 \\
\hline & Older than 45 & 20 & 24.40 & \\
\hline \multirow[t]{2}{*}{ Interpersonal relations } & Younger than 45 & 28 & 29.68 & .002 \\
\hline & Older than 45 & 20 & 17.25 & \\
\hline \multirow[t]{2}{*}{ Material wellbeing } & Younger than 45 & 28 & 26.11 & .336 \\
\hline & Older than 45 & 20 & 22.25 & \\
\hline \multirow[t]{2}{*}{ Physical wellbeing } & Younger than 45 & 27 & 25.72 & .314 \\
\hline & Older than 45 & 20 & 21.68 & \\
\hline
\end{tabular}


With regard to gender, the data demonstrated that women presented higher quality of life indices, although there were no significant differences: $\mathrm{p}=.158$.

Table 4. Analysis of the quality-of-life index by gender and age with the Mann-Whitney U test

\begin{tabular}{lcccc}
\cline { 2 - 5 } & N & Mean & SD & p \\
\hline Men younger than 45 & 13 & 15,08 & 5,123 & \\
Men older than 45 & 16 & 12,50 & 5,621 & .043 \\
Women younger than 45 & 14 & 16,36 & 4,717 & \\
Women older than 45 & 4 & 13,75 & 2,630 & \\
Total & 47 & 14,47 & 5,145 & \\
\hline
\end{tabular}

$\mathrm{P}$ for all $=.660>\mathrm{p}<.179$; except signed at table.

If we compare the gender of the sample with each one of the dimensions, women with disability had higher scores for all of them, except for physical wellbeing $(\mathrm{h}=25,76 ; \mathrm{m}=22.58)$, having significant differences for the dimension of self-determination $(\mathrm{p}=.013)$, and emotional wellbeing $(\mathrm{p}=.0047)$.

Table 5. Means test of the scores of the dimensions of quality of life by gender

\begin{tabular}{|c|c|c|c|c|}
\hline & Gender & $\mathbf{N}$ & Average & p \\
\hline \multirow[t]{2}{*}{ Self-determination } & Men & 30 & 21.02 & .013 \\
\hline & Women & 19 & 31.29 & \\
\hline \multirow[t]{2}{*}{ Rights } & Men & 30 & 23.80 & .452 \\
\hline & Women & 19 & 26.89 & \\
\hline \multirow[t]{2}{*}{ Emotional wellbeing } & Men & 30 & 24.52 & .763 \\
\hline & Women & 19 & 25.76 & \\
\hline \multirow[t]{2}{*}{ Social inclusion } & Men & 30 & 23.72 & .426 \\
\hline & Women & 19 & 27.03 & \\
\hline \multirow[t]{2}{*}{ Personal development } & Men & 30 & 22.07 & .062 \\
\hline & Women & 19 & 29.63 & \\
\hline \multirow[t]{2}{*}{ Interpersonal relations } & Men & 30 & 22.25 & .088 \\
\hline & Women & 19 & 29.34 & \\
\hline \multirow{2}{*}{ Material wellbeing } & Men & 30 & 21.85 & .047 \\
\hline & Women & 19 & 29.97 & \\
\hline \multirow[t]{2}{*}{ Physical wellbeing } & Men & 29 & 25.76 & .438 \\
\hline & Women & 19 & 22.58 & \\
\hline
\end{tabular}


With regard to training and quality of life, the results showed that the people with some type of training presented high quality of life indices. The scores pointed to significant differences $(\mathrm{p}=.047)$

The values obtained for the different dimensions in relation to training demonstrated that the people with some type of training had higher average scores in all dimensions except for rights (yes $\bar{X}=9.00$; no $\bar{X}=9.29$ ), although there were no significant differences for that dimension. Differences were found for the dimensions of emotional wellbeing $(p=.046)$, social inclusion $(p=.056)$ and interpersonal relations $(\mathrm{p}=.004)$.

\section{DISCUSSION}

The aging of people with IDD often appears prematurely, at around 45 years of age, and this reality has a significant impact on the people who are working (Dykens, 2018, Berjano \& García, 2010).

In line with the results of the study completed by Solis, Alcedo, Fontanil, Pedrosa and Aguado (2019), this situation especially affects the Special Employment Centres (CEE), with a high number of workers with intellectual disability, and with an older staff, as many were born in the decade of the 1980s.

The results of this investigation concurred with the conclusions advanced by Prasher and Janicki (2019), who affirmed that the aging process affected the different dimensions of quality of life. In relation with the dimension of physical and material wellbeing, as is concluded in this study, and in line with the proposals of Aguado et al. (2010), aging reduced the quality of life, as it was associated with greater susceptibility to tiredness, the appearance of pain, and mobility problems, but problems of cognitive deterioration were especially evident with regard to the general population.

Emotional wellbeing recorded lower satisfaction scores at the aging stage than at early ages, a factor that might be related, as Dykens (2018) and Berzosa (2013) made clear, to the fact that enormous uncertainty regarding the future is generated at that stage of life, added to the emotional problems associated with the loss of a loved one.

In contrast, the lack of guaranties with regard to economic rights are a source of concern, with retirement conditions unavailable to many people with IDD who are aging prematurely. Moreover, flexible labor conditions are not guaranteed, with neither internal transfers between services, nor compatibility with different types of employment activity (Stacy, Leader, Kosciulek, Leahy, 2015).

The results on the gender of the people with disability in this study coincided with the conclusions of the work completed by Larrayoz, (2013), who highlighted the higher average scores of women in all dimensions as against men. However, we found differences with regard to the minimum values, because the lowest means obtained for women in the aforementioned study were for personal development, unlike in this study where physical wellbeing showed the lowest scores.

With respect to training, our study is aligned with the affirmations of Laborda and González (2017): a direct relation with quality of life, and a greater level of training linked to greater satisfaction referring to the different dimensions. 
Taking into account the earlier results, the negative consequences of aging for workers with intellectual disability on their quality of life and their employment activity were notable. The debate is at present centered on how to mitigate the negative impact for the person of leaving employment that would be produced both in their personal relations and in their emotional development. Without forgetting the repercussion of economic loss and the difficulty of complementing their leisure time that would earlier have been more active with workmates (Berjano \& García, 2010).

In the framework of this situation, it is necessary to propose alternatives within the CEE, which must find responses to the needs of people who are aging, which would imply coordination between administrations, families, and disability support organizations (Novell et al., 2008; Elorriaga el at., 2012).

\section{Conclusions}

In our study, we have analyzed how aging and premature deterioration among workers with disability, considered here from 45 years of age, impacts on their quality of life.

The results point to the importance of the variable age as an influential factor in the indices of quality of life that are manifest from their lower scores for emotional wellbeing, social inclusion, and interpersonal relations, among others, as well as differences according to gender and group training.

With regard to the relation between the gender of the people with IDD and their quality of life, the results of our study have pointed out that the women presented higher scores for quality of life, highlighting that they have clear goals, more autonomy, problem-solving capabilities, and daily life skills. However, it is the dimension of physical wellbeing where women had the lowest scores.

In contrast, from the data we have obtained we can affirm that the people with greater training have a better quality of life. According to the results obtained from the different dimensions under analysis, having some type of training means that people with IDD will feel greater satisfaction with life, have a better self-image, an absence of negative feelings (emotional wellbeing, more integration, participation, and support in society (social inclusion) and their family, social, and sexual-affective relations (interpersonal relations) are better. Having some type of training means that those variables will improve.

We could conclude by affirming that, in general terms, the studies on intellectual disability and aging, coincide, in so far as they distinguish two types of consequences for the age-related deterioration of the workers at CEEs that affect their quality of life. Some are directly associated with employment aspects, such as a reduction in the rhythm of work, precision in the task, weaker motivation, an increase in absenteeism, and the loss of higher faculties such as attention and the slower reflexes. Many of those faculties increase the risk of suffering accidents at work. On the other hand, a series of changes take place that affect personality features, such as changes of mood, greater irritability, and the accentuation of behavioral disorders.

It is necessary to find a valid alternative for the future of those workers with IDD who have progressively to leave employment. In that sense, the measures that are established must respond to

(C) Psy, Soc, \& Educ, 2020, Vol. 12(2) 
each one of the Projects of life of the workers, and they should be oriented along two vectors: some directed at applying measures during the last phase of their working life and others focused on a model of intervention that will not imply rupture, and that has the least possible impact on the person, on their economy and likewise for the family.

\section{Bibliographic References}

Aguado, A. y Alcedo, M.A. (2004): Necesidades percibidas en el proceso de envejecimiento de las personas con discapacidad. Psicothema, 16, 261-269. dc.identifier.uri: http://hdl.handle. net/10651/26739

Aguado, A.; Alcedo, M.A.; Rozada, C.; González, M.; Real, S. y Fontanil, Y. (2010): “Calidad de vida y necesidades percibidas de las personas con discapacidad intelectual en proceso de envejecimiento en Castilla y León: avance de resultados”, en Verdugo, M.A. (Coord.) Aplicación del paradigma de Calidad de Vida. Salamanca. Inico. 117-137.

Bayarri, V. (2003): Envejecimiento y deterioro de las personas con discapacidad intelectual en el ámbito del empleo en la Comunidad Foral de Navarra. Navarra, Koine -Aequalitas y FEAPS Navarra.

Berjano, E. y García, E. (2010): Discapacidad intelectual y envejecimiento: un problema social del S. XXI. Madrid, Colección FEAPS.

Berzosa, G. (dir.) (2013). Las personas con sindrome de Down y sus familias ante el proceso de envejecimiento. Madrid. Real Patronato sobre Discapacidad.

Cayo, L y Andreu, A (2012) (Dirs): El envejecimiento de las personas con discapacidad. Documento de posición del CERM estatal. Madrid. Ediciones Cinca.

Del Barrio, J.A. y Santurde, E. (2015): Envejecimiento, discapacidad intelectual, calidad de vida. Situación y necesidades. INFAD Revista de Psicología, 2, 55-66. https://doi.org/10.17060/ ijodaep.2015.n1.v2.98

Dirección General de Economía Social (2018): Plantilla de trabajadores con discapacidad de los Centros Especiales de Empleo en Castilla y León. Junta de Castilla y León.

Dykens, EM (2018). Aging in rare intellectual disability syndromes. Dev Disabil Res Rev. 18(1):75-83. https://doi.org/10.1002/ddrr.1130

Elorriaga, E.; Restrepo W.; Bayarri, V. y Fillat, Y. (2012): Envejecimiento y deterioro de las personas con discapacidad intelectual en el ámbito ocupacional y de empleo en Bizkaia. Zerbitzuan, 51, 119-135. http://dx.doi.org/10.5569/1134-7147/51.08

Laborda, C. y González, H. (2017). Trabajo protegido. La orientación como herramienta para mejorar la calidad de vida. REOP, 28, 82-98. Disponible en: https://www.redalyc.org/ articulo.oid $=338254890004$

Larrayoz, A. (2013). Calidad de vida y experiencias de inserción laboral de personas con discapacidad intelectual en la Administración Pública de la Comunidad Foral de Navarra. (Trabajo de Fin de Master). Universidad pública de Navarra. Comunidad Foral de Navarra.

Navas, P; Uhlmann, S. y Berastegui, A. (2014): Envejecimiento activo y discapacidad intelectual. Madrid. Ministerio de Educación, Cultura y Deporte. 
Novell, R.; Nadal, M.; Smilges, A.: Pascual, J. y Pujol, J. (2008) Informe Séneca. Envejecimiento y Discapacidad Intelectual en Cataluña 2000-2008. Federación Catalana Pro-personas con discapacidad Intelectual. En http://www.dincat.cat/fichero-21051_21051.

Otamendi, N y Navas, P. (2018): Calidad de vida de personas con discapacidad intelectual en procesos de envejecimiento en entornos de vivienda. Revista Española de Discapacidad" 6 (II), 27-47. http://dx.doi.org/10.5569/2340-5104.

Prasher, V.; Janicki, M. (Editors). (2019). Physical Health of Adults with Intellectual and Developmental Disabilities. Springer International Publishing. DOI: 10.1007 / 978-3-31990083-4.

Rafanell, A. (2017): Envejecimiento y discapacidad intelectual: una doble dependencia. Informaciones psiquiátricas, 228, 71-77. Disponible en: Rodríguez, P. (2010): "El envejecimiento de las personas con discapacidad, la discapacidad de las personas mayores, las situaciones de dependencia y las claves para el diseño de un modelo de intervención" en Discapacidad, Tercer sector e inclusión social. Madrid, Ediciones Cinca, 367-399.

Schalock, R.L. y Verdugo, M.A. (2002). The concept of quality of life in human services: A handbook for human service practitioners. Washington, DC: American Association on Mental Retardation.

Solis, P.; Alcedo, MA.; Fontanil, Y.; Pedrosa, I.; Aguado, A. (2019). El proceso de envejecimiento en personas con discapacidad intelectual. Servicios Sociales y Política Social. 119; 63-76.

Stacy, S.; Leader, G.; Kosciulek, J.; Leahy, M. (2015). Defining social inclusion of people with intellectual and developmental disabilities: An ecological model of social networks and community participation. Research in Developmental Disabilities.Vol. 38, 18-29.https:// doi.org/10.1016/j.ridd.2014.10.008

Verdugo, M. A.; Rodríguez, A. y Sánchez, M.C. (2009) Familias y personas con discapacidad intelectual en procesos de envejecimiento. La doble dependencia. Madrid, Síntesis.

Verdugo, M.A.; Gómez, L.; Arias, B.; Santamaría, M.; Clavero, D; Tamarit, J. (2013): Escala INICO-FEAPS. Evaluación integra de la Calidad de Vida de las personas con Discapacidad Intelectual o del Desarrollo. Salamanca: INICO.

Verdugo, M.A., Schalock, R.L., Arias, B., Gómez, L. y Jordán, B. (2013). Calidad de vida. En M.A. Verdugo y R.L. Schalock (Coords.), Discapacidad e Inclusión: manual para la docencia, 443-461. Salamanca: Amarú.

Vidriales, R.; Hernández, C. y Plaza, M. (2016): Envejecimiento y trastorno del espectro autista. Una etapa vital invisible. Madrid. Autismo España. 